\title{
STUDI PENGGUNAAN ANTIBIOTIK PADA PASIEN DEMAM TIFOID DI RS SMC PERIODE 2017
}

\author{
Khoirunnisa Wal Hazimah ${ }^{1, \dagger}$, Mukti Priastomo ${ }^{1}$, Rolan Rusli ${ }^{1,2, \sharp}$ \\ ${ }^{1}$ Laboratorium Penelitian dan Pengembangan Kefarmasian "Farmaka Tropis", \\ Fakultas Farmasi, Universitas Mulawarman, Samarinda, Indonesia \\ †Email: khoirunnisawh@gmail.com \\ ${ }^{2}$ Kelompok Bidang Ilmu Kimia Farmasi, Fakultas Farmasi, \\ Universitas Mulawarman, Samarinda, Indonesia \\ *Email: rolan@farmasi.unmul.ac.id
}

\begin{abstract}
ABSTRAK
Penyakit demam tifoid merupakan infeksi akut pada usus halus yang disebabkan oleh bakteri Salmonella typhi dengan gejala demam lebih dari satu minggu. Terapi utama pengobatan demam tifoid yaitu menggunakan antibiotik, yang dapat menyebabkan resistensi. Sehingga dibutuhkan studi terkait penggunaan antibiotik pada pasien demam tifoid. Penelitian dilakukan dengan pendekatan retrospektif pada 79 data pasien demam tifoid. Hasil penelitian menunjukkan bahwa penderita demam tifoid terbanyak adalah perempuan $(53,16 \%)$ dengan usia kanak-kanak (6-11 tahun) dan masa dewasa awal (26-35 tahun) sebesar $17,72 \%$. Penggunaan antibiotik terbanyak digunakan adalah adalah golongan sefalosporin $(56,96 \%)$ yakni seftriakson, dengan frekuensi pemberian yaitu sekali dalam sehari. Selain penggunaan antibiotik, diberikan pula terapi suportif seperti antipeuretik, $\mathrm{H}-2$ bocker dan anti mual muntah.
\end{abstract}

Kata Kunci: Antibiotik, Demam Tifoid, Siprofloksasin

DOI: https://doi.org/10.25026/mpc.v7i1.290

\section{PENDAHULUAN}

Demam tifoid termasuk dalam 10 besar masalah kesehatan di negara berkembang dengan prevalensi $91 \%$ pada pasien anak [1]. Demam tifoid merupakan penyakit endemis yang disebabkan oleh Salmonella typhi yang menginfeksi saluran pencernaan sehingga mengakibatkan peradangan pada bagian usus halus dan lumen usus [2]

Berdasarkan Profil Kesehatan Indonesia pada tahun 2012, demam tifoid atau paratifoid juga menempati urutan ke3 dari 10 penyakit terbanyak dari pasien rawat inap di rumah sakit tahun 2010 yaitu sebanyak 41.081 kasus dan yang meninggal 274 orang dengan Case Fatality Rate sebesar 0,67 \% [3].

Antibiotik merupakan obat yang paling banyak digunakan pada infeksi yang disebabkan oleh bakteri. Berbagai studi menemukan bahwa sekitar 40-62\% antibiotik digunakan secara tidak tepat antara lain untuk penyakit-penyakit yang sebenarnya tidak memerlukan antibiotik. Pada penelitian kualitas penggunaan antibiotik di berbagai bagian rumah sakit 
ditemukan 30\% sampai dengan 80\% tidak didasarkan pada indikasi [4].

Hal tersebut meningkatkan peluang terjadinya insiden penggunaan antibiotik yang tidak rasional yang dapat menyebabkan kejadian resistensi antibiotik. Resistensi antibiotik telah menjadi perhatian masyarakat di seluruh belahan dunia, hal tersebut memerlukan kesadaran bersama akan adanya hubungan antara tingkat resistensi antibiotik dengan pola penggunaan antibiotik. Informasi mengenai pola penggunaan antibiotik dapat digunakan sebagai sumber informasi dalam pengendalian resistensi antibiotik [5]. Berdasarkan hal tersebut maka dilakukan studi mengenai penggunaan antibiotik pada pasien demam tifoid di RS Samarinda Medika Citra.

\section{METODE PENELITIAN}

Penelitian ini dilakukan secara retrospektif dengan mengambil data dari rekam medik pasien rawat inap penderita demam tifoid di RS Samarinda Medika Citra pada periode Januari hingga Desember 2017. Data dikumpulkan berdasarkan kriteria inklusi yaitu mempunyai hasil uji laboratorium yang menandakan positif demam tifoid, menggunakan antibiotik, dan pasien memiliki data rekam medik yang lengkap. Data yang didapatkan dianalisis secara deskriptif.

\section{HASIL DAN PEMBAHASAN}

Penelitian ini dilakukan di RS Samarinda Medika Citra dengan mengumpulkan data rekam medik pasien rawat inap yang menderita demam tifoid pada periode Januari hingga Desember 2017. Sampel yang digunakan yaitu pasien demam tifoid yang mendapatkan antibiotik dan masuk kedalam kriteria inklusi. Jumlah pasien yang didapatkan sebanyak 79 pasien dengan distribusi karakteristiknya dapat dilihat pada tabel 1.
Berdasarkan tabel 1 terlihat bahwa jumlah penderita demam tifoid terbanyak adalah perempuan $(53,16 \%)$ dibandingkan laki-laki $(46,84 \%)$. Hal ini diduga karena perempuan sering membeli makanan di luar rumah yang diduga makanan tersebut kurang sehat, karena penyakit ini sangat erat kaitannya dengan kebersihan kehidupan seseorang dari makanan maupun lingkungan yang kumuh dan biasanya transmisi penularan terjadi melalui air yang tercemar Salmonella typhi, makanan atau minuman sehingga kejadian demam tifoid dapat terjadi kepada siapapun. Akan tetapi secara teori tidak ada hubungan yang bermakna antara jenis kelamin dengan kejadian demam tifoid. Demam tifoid dapat terjadi pada semua jenis kelamin baik pada perempuan maupun laki-laki dan hal ini bukan merupakan indikasi bahwa kejadian demam tifoid lebih banyak pada perempuan dibandingkan laki-laki.

Pada data karakteristik pasien penderita demam tifoid berdasarkan usia menunjukkan bahwa kejadian demam tifoid terbanyak pada usia kanak-kanak (6-11 tahun) dan masa dewasa awal (2635 tahun) yaitu sebesar $17,72 \%$. Hal ini dikarenakan pada kelompok umur 6-11 tahun merupakan usia sekolah dimana pada kelompok usia tersebut sering melakukan aktifitas di luar rumah dan sering membeli makanan atau minuman di luar rumah yang kurang terjamin kebersihannya, sehingga beresiko terinfeksi Salmonella typhi. Sedangkan pada usia 26-35 tahun hal ini diduga karena pada usia tersebut merupakan usia produktif dalam berkerja sehingga terlalu sibuk bekerja sampai kurang memperhatikan kesehatan dan pola makan, serta memilih gaya hidup yang kurang sehat seperti membei jajan diluar maupun memakan makanan instan, yang menyebabkan daya tahan tubuh terhadap penyakit menjadi kurang. 
Tabel 1. Distribusi Jenis Kelamin dan Usia Pasien Demam Tifoid di RS Samarinda Medika Citra periode 2017

\begin{tabular}{lcc}
\hline Data Karakteristik & Jumlah Pasien & Persentase (\%) \\
\cline { 1 - 2 } Jenis Kelamin & 37 & \\
Laki-laki & 42 & 46,84 \\
Perempuan & 79 & 53,16 \\
\hline Total & & 100 \\
\hline Usia & 10 & 12,65 \\
\cline { 1 - 2 } Balita (0-5 tahun) & 14 & 17,72 \\
Kanak-kanak (6-11 tahun) & 5 & 6,32 \\
Remaja Awal (12-16 tahun) & 11 & 13,92 \\
Remaja Akhir Tahun (17-25 tahun) & 14 & 17,72 \\
Dewasa Awal Tahun (26-35 tahun) & 6 & 7,59 \\
Dewasa Akhir Tahun (36-45 tahun) & 13 & 16,45 \\
Lansia Awal Tahun (46-55 tahun) & 6 & 7,59 \\
Lansia Akhir (56-65 tahun) & 0 & 0 \\
Lansia (65 tahun keatas) & 79 & 100 \\
\hline Total & & \\
\hline
\end{tabular}

Tabel 2. Profil Pengobatan Pasien Demam Tifoid di RS Samarinda Medika Citra periode 2017

\begin{tabular}{cccc}
\hline Golongan Antibiotik & Jenis Antibiotik & Jumlah & Persentase (\%) \\
\hline Sefalosporin & Seftriakson & 45 & 56,96 \\
& Septik Sirup & 2 & 2,53 \\
& Sefadroksil & 7 & 8,86 \\
Penisilin & Sanpicilin & 22 & 27,84 \\
& Amoxicilin & 5 & 6,32 \\
Kuinolon & Siprofloksasin & 12 & 15,18 \\
Sulfanamida & Kotrimoksazol & 1 & 1,26 \\
Kloramfenikol & Colsancentine & 7 & 8,86 \\
\hline
\end{tabular}

Pengobatan Pada Pasien Demam Tifoid

Pada tabel 2 diperoleh profil pengobatan dalam penggunaan antibiotik berupa golongan dan jenis obat yang digunakan dalam pengobatan pasien demam tifoid di RS Samarinda Medika Citra periode tahun 2017 diantaranya golongan antibiotik sefalosporin, penisilin, kuinolon, sulfanamida, dan kloramfenikol. Penggunaan antibiotik yang paling banyak digunakan ialah golongan sefalosporin dengan jenis antibiotik seftriakson yaitu sebesar 56,96
$\%$. Seftriakson merupakan antibiotik golongan sefalosforin generasi ketiga.

Pemberian Seftriakson pada pasien Demam tifoid dikarenakan Seftriakson merupakan antibiotik spektrum luas, yaitu antibiotik yang memiliki efek terhadap bakteri gram positif maupun negatif, termasuk Salmonella typhi penyebab demam tifoid [6]. Seftriakson ini memiliki kerja menghambat sintesis dinding sel bakteri dengan berikatan dengan satu atau lebih ikatan proteinpenisilin (penicillin-binding proteinsn/PBPs) yang selanjutnya akan menghambat tahap transpeptidasi sintesis 
peptidoglikan dinding sel bakteri sehingga menghambat biosintesis dinding sel. Bakteri akan mengalami lisis karena aktivitas enzim autolitik (autolisin dan murein hidrolase) saat dinding sel bakteri terhambat [7].

Pada terapi pengobatan demam tifoid mempunyai lini pertama salah satunya yaitu koramfenikol, sedangkan golongan sefalosporin berupa seftriakson merupakan terapi pengobatan lini kedua. Pada data tersebut dapat dilihat bahwa penderita demam tifoid banyak yang diberikan seftriakson. Berdasarkan studi penelitian Sidabutar (2010) lebih menganjurkan pemberian seftriakson dibandingkan kloramfenikol untuk pasien demam tifoid yang dirawat di rumah sakit dikarenakan perbedaan yang mendasar pada kedua antibiotik ini adalah lamanya demam turun lebih cepat sehingga lama terapi lebih singkat, efek samping lebih ringan, dan angka kekambuhan yang lebih rendah pada penggunaan seftriakson dibandingkan kloramfenikol. Durasi terapi seftriakson bervariasi antara 3-10 hari dengan waktu demam turun rata-rata empat hari. Selain itu, Efek samping yang mungkin ditemukan karena pemberian kloramfenikol adalah supresi sumsum tulang.

Pemberian seftriakson sebagai terapi empiris pada pasien demam tifoid secara bermakna dapat mengurangi lama pengobatan dibandingkan dengan pemberian jangka panjang kloramfenikol. Hal lain yang menguntungkan adalah efek samping dan angka kekambuhan yang lebih rendah, serta lama demam turun yang lebih cepat [8].

\section{Frekuensi Pemberian Obat Antibiotik}

Dari tabel 3 didapatkan data bahwa frekuensi pemberian antibiotik yang terbanyak yaitu seftriakson $1 \times 1$ (sekali dalam sehari). Seftriakson memiliki waktu paruh 6,5-8,6 jam pada orang dewasa dan 6-7,4 jam pada anak-anak [6] sehingga dapat diberikan sehari sekali. Ketika obat memiliki frekuensi sehari sekali yang mana menunjukkan bahwa obat bekerja selama onset yang panjang sehingga diharapkan pasien penderita demam tifoid yang diduga mendapatkan terapi suportif yang menggunakan beberapa obat lainnya sehingga pasien tidak mengkonsumsi obat yang pemberiannya berulang dan banyak obat lainnya.

Tabel 3. Profil Frekuensi Pemberian Antibiotik Pasien Demam Tifoid di RS Samarinda Medika Citra periode 2017

\begin{tabular}{cccc}
\hline Jenis Antibiotik & Frekuensi & Jumlah & Persentase (\%) \\
\hline Seftriakson & $1 \times 1$ & 31 & 39,24 \\
& $2 \times 1$ & 14 & 17,72 \\
Septik Sirup & $2 \times 1$ & 2 & 2,53 \\
Sefadroksil & $2 \times 1$ & 7 & 8,86 \\
Sanpicilin & $3 \times 1$ & 16 & 20,25 \\
& $4 \times 1$ & 6 & 7,59 \\
Amoxicilin & $3 \times 1$ & 5 & 6,32 \\
Siprofloksasin & $2 \times 1$ & 12 & 15,18 \\
Kotrimoksazol & $2 \times 1$ & 1 & 1,26 \\
Colsancentine & $3 \times 1$ & 2 & 2,53 \\
& $4 \times 1$ & 5 & 6,32 \\
\hline
\end{tabular}


Tabel 4. Profil Terapi Penyakit Penyerta Pasien Demam Tifoid di RS Samarinda Medika Citra periode 2017

\begin{tabular}{|c|c|c|c|}
\hline No. & Golongan & Jumlah & Persentase $(\%)$ \\
\hline & H-2 Blocker & & \\
\hline 1 & Ranitidin & 57 & 72,15 \\
\hline \multirow[t]{2}{*}{2} & Gastridin & 4 & 5,06 \\
\hline & Anti Mual-Muntah & & \\
\hline 1 & Ondansentron & 43 & 54,43 \\
\hline \multirow[t]{2}{*}{2} & Domperidon & 4 & 5,06 \\
\hline & Antipeuritik & & \\
\hline \multirow[t]{2}{*}{1} & Paracetamol & 79 & 100 \\
\hline & Antihistamin & & \\
\hline 1 & Lapifed & 11 & 13,92 \\
\hline 2 & Ketrizin & 3 & 3,79 \\
\hline 3 & Betahistin & 2 & 2,53 \\
\hline \multirow[t]{2}{*}{4} & Trifed & 1 & 1,26 \\
\hline & Proton Pump Inhibitor & & \\
\hline 1 & Omeprazol & 6 & 7,59 \\
\hline 2 & Lansoprazol & 9 & 11,39 \\
\hline 3 & Pantoprazol & 2 & 2,53 \\
\hline
\end{tabular}

\section{Terapi Penyakit Penyerta}

Berdasarkan tabel 4 terdapat banyak obat yang diberikan pada pasien demam tifoid yang memiliki diagnosis penyakit penyerta. Obat yang digunakan untuk mengatasi penyakit penyerta paling banyak digunakan ialah antipeuretik sebesar $100 \%$ yang berfungsi untuk menurunkan demam yang terjadi pada pasien demam tifoid. Selain itu adapula golongan H-2 blocker sebesar 72,15\% yang berfungsi untuk menetralisir atau mengurangi produksi asam lambung dan golongan anti mual muntah sebesar $54,43 \%$ yang mana diketahui bahwa efek samping dari penggunaan antibiotik sebagian besar menimbulkan gangguan gastrointestinal berupa mual muntah.

\section{KESIMPULAN}

Berdasarkan hasil penelitian studi penggunaan antibiotik pada pasien demam tifoid di RS SMC pada periode 2017 yang telah dilakukan dapat disimpulkan bahwa :

1. Karakteristik pasien penderita demam tifioid terbanyak diderita oleh perempuan dengan persentase $53,16 \%$ dan berusia usia 6 hingga 11 tahun dan 26 hingga 35 tahun sebanyak $17,72 \%$.

2. Penggunaan antibiotik terbanyak adalah seftriakson seesar 56,96\% dengan frekuensi pemberian obat antibiotik yaitu $1 \times 1$ (sekali dalam sehari).

3. Terapi penyakit penyerta yang paling banyak digunakan yaitu golongan antipeuretik berupa paracetamol, golongan H-2 blocker berupa ranitidine dan golongan anti mual muntah yaitu ondansentron.

\section{DAFTAR PUSTAKA}

[1] Pudjiadi, A.H., et all. 2009. Pedoman Pelayanan Medis Ikatan Dokter Anak Indonesia. Badan Penerbit Ikatan Dokter Anak Indonesia: Jakarta.

[2] Etikasari, R. et all. 2012. Analisis Biaya dan Kesesuaian Penggunaan Antibiotik pada Demam Tifoid di RSUD Kota Yogyakarta. Jurnal Manajemen dan Pelayanan Farmasi (JMPF ) Pract. 2. 147-153 
[3] Kementerian Kesehatan Republik Indonesia. 2012. Profil Kesehatan Indonesia 2012. Kementerian Kesehatan Republik Indonesia : Jakarta.

[4] Hadi, U. 2009. Resistensi Antibiotik, Buku Ajar Ilmu Penyakit Dalam,Edisi V, Jilid III, Interna Publishing: Jakarta.

[5] Marhamah. 2009, Evaluasi Penggunaan Antibiotik Pada Pasien Demam Tifoid Di Instalasi Rawat Inap RSUD Pambalah Batung Kabupaten Hulu Sungai Utara Kalimantan Selatan tahun 2009, Fakultas Farmasi, Universitas Muhammadiyah Surakarta.
[6] Handoyo, Y. 2011. Pengobatan Demam Tifoid dengan Seftriakson atau Kloramfenikol Di Rumah Sakit Swasta Tangerang. Bina Widya 22 (4): 2004.

[7] Mycek, M. J, Harvey, R.A. dan Champe, P.C., 2001, Farmakologi Ulasan Bergambar 2nd Widya Medika: Jakarta.

[8] Sidabutar S, Irawan Hindra S, 2010, Pilihan Terapi Empiris Demam Tifoid pada Anak: Kloramfenikol atau Seftriakson?. Jurnal Sari Pediatri. Vol. 11, No. 6: Fakultas Kedokteran Universitas Indonesia, Jakarta. 